\title{
DAMPAK PENCEMARAN AKTIVITAS KENDARAAN BERMOTOR TERHADAP KANDUNGAN TIMBAL (PB) DALAM TANAH DAN TANAMAN PADI
}

\author{
The Impact of Pollution Motor Vehicle Activities to Lead (Pb) Content in Soil and Rice Plant
}

\author{
Listin Fitrianah ${ }^{\mathrm{a}}$, Mohammad Yani ${ }^{\mathrm{b}}$, Sobri Effendy ${ }^{\mathrm{c}}$ \\ ${ }^{a}$ Program Studi Pengelolaan Sumberdaya Alam dan Lingkungan (PSL), Institut Pertanian Bogor, Kampus IPB \\ Darmaga, Bogor 16680 - listin.fitrianah@gmail.com \\ ${ }^{\mathrm{b}}$ Departemen Teknologi Industri Pertanian, Fakultas Teknik Pertanian dan Teknologi Pertanian, Institut Pertanian \\ Bogor, Kampus IPB Darmaga, Bogor 16680 \\ ${ }^{\mathrm{c}}$ Departemen Geofisika dan Meteorologi, Fakultas Matematika dan Ilmu Pengetahuan Alam, Institut Pertanian \\ Bogor, Kampus IPB Darmaga, Bogor 16680
}

\begin{abstract}
The increasing volume and activities of motor vehicles caused to increase gasoline consumption and air pollutants such as lead $(\mathrm{Pb})$. In an ambient environment, lead will be deposited in the soil and absorbed by plants. This study was conducted to assess lead content in soil and plantespecially at the rice field at Lamongan, that caused by motor vehicles activities. Activities of motor vehicles along main roads were identified as well as assessing of the lead emission. Deposition of lead from ambient were observed in the soil and rice plant with a distance of $100 \mathrm{~m}, 1000 \mathrm{~m}$, and $2000 \mathrm{~m}$ from road side (north and south) and analyzed before and after rice planting. The lead content in rice plants highest at north side of $100 \mathrm{~m}$, while the lowest was found in rice plant south side with a distance of $2000 \mathrm{~m}$. Lead content in the highest rice bean found in rice plant north side of $100 \mathrm{~m}$, while the lowest was found in rice paddies south side of the road a distance of $2000 \mathrm{~m}$.
\end{abstract}

Keywords: lead, motor vehicles, plant, soil

(Diterima: 18-06-2016; Disetujui: 22-07-2016)

\section{Pendahuluan}

Perkembangan kendaraan bermotor sangat memudahkan manusia dalam melaksanakan suatu pekerjaan, namun di sisi lain pemakaian kendaraan bermotor yang digunakan sebagai moda transportasi dapat menimbulkan dampak buruk terhadap lingkungan. Laju pertumbuhan kepemilikan kendaraan bermotor yang tinggi. Sebagian besar kendaraan bermotor itu menghasilkan emisi gas buang yang buruk, baik akibat perawatan yang kurang memadai ataupun dari penggunaan bahan bakar dengan kualitas kurang baik. Pemakaian kendaraan bermotor yang menggunakan bahan bakar fosil, memiliki peran yang cukup besar dalam pencemaran lingkungan. Pencemaran logam berat terhadap lingkungan merupakan suatu proses yang sangat erat hubungannya dengan penggunaan logam atau persenyawaan logam tersebut oleh manusia. Pencemaran ini disebabkan oleh gas buangan sisa pembakaran bahan bakar kendaraan bermotor

Keberadaan akses penghubung utama di Kabupaten Lamongan membawa konsekuensi meningkatnya aktivitas kendaraan bermotor. Meningkatnya aktivitas kendaraan bermotor tentunya berdampak terhadap timbulnya bahan pencemar. Salah satu bahan pencemar yang dihasilkan dari aktivitas kendaraan bermotor sebagai akibat dari pembakaran bensin adalah timbal $(\mathrm{Pb})$. Timbal $(\mathrm{Pb})$ merupakan bahan yang dapat meracuni lingkungan dan mempunyai doi: 10.19081/jps1.2017.7.1.11 dampak pada seluruh sistem di dalam tubuh. Timbal $\mathrm{Pb})$ dapat masuk ke tubuh melalui inhalasi, makanan dan minuman serta absorbsi melalui kulit.

Emisi $\mathrm{Pb}$ dari gas buangan tetap akan menimbulkan pencemaran udara dimanapun kendaraan itu berada, tahapannya adalah sebagai berikut: sebanyak $10 \%$ akan mencemari lokasi dalam radius kurang dari 100 $\mathrm{m}, 5 \%$ akan mencemari lokasi dalam radius $20 \mathrm{~km}$, dan $35 \%$ lainnya terbawa atmosfer dalam jarak yang cukup jauh (Surani, 2002). Tingginya aktivitas kendaraan bermotor sebagai akibat dari keberadaan jalan nasional tentunya akan berdampak terhadap akumulasi bahan pencemar $(\mathrm{Pb})$ yang dimungkinkan akan terserap oleh tanah dan tanaman padi.

Timbal merupakan unsur yang tidak esensial bagi tanaman, kandungannya berkisar antara 0,1-10 ppm (Soepardi, 1983), dan kandungannya dalam tanaman untuk berbagai jenis secara normal berkisar 0,5-3,00 ppm. Tanaman tertentu tingkat keracunan terhadap timbal sangat tinggi. Hal tersebut menimbulkan kondisi yang membahayakan, karena dalam tanaman tidak menunjukkan gejala keracunan dan kelihatan sehat, tetapi berbahaya jika tanaman dikonsumsi manusia dan hewan. Menurut Dahlan (1989) tingkat akumulasi timbal pada vegetasi dan tanah akan meningkat seiring dengan meningkatnya kepadatan arus lalu lintas dan menurun bila semakin jauh dari tepi jalan raya. Faktor-faktor yang mempengaruhi kadar timbal dalam tanaman yaitu jangka waktu tanaman kontak dengan timbal, kadar timbal dalam 
tanah, morfologi dan fisiologi tanaman, umur tanaman dan faktor yang mempengaruhi lahan seperti banyaknya tanaman penutup serta jenis tanaman di sekeliling tanaman tersebut. Dua jalan masuknya timbal ke dalam tanaman yaitu melalui akar dan daun. Timbal setelah masuk ke sistem tanaman akan diikat oleh membran-membran sel, mitokondria dan kloroplas. Bahkan timbal dapat menyebabkan terjadinya kerusakan fisis. Kerusakan tersembunyi dapat berupa penurunan kemampuan tanaman dalam menyerap air, pertumbuhan yang lambat atau pembukaan stomata yang tidak sempurna.

Penelitian ini dilakukan dengan tujuan: Mengevaluasi sebaran pencemaran timbal dari aktivitas kendaraan bermotor terhadap areal persawahan dan kandungan timbal pada tanah serta tanaman padi.

\section{Metode Penelitian}

\subsection{Alat dan Bahan}

Alat dan bahan yang digunakan dalam penelitian ini antara lain berupa peta administrasi, peta tanah, peta penggunaan lahan, sampel tanah, sampel tanaman padi. Seperangkat alat komputer dengan perangkat lunak
ArcGIS 9.3, Microsoft Excel, Microsoft Word, Microsoft Visio, peta administrasi, peta tanah, Global Positioning Sytem (GPS), wadah sampel, software SAS (Statistical Analysis System) dan Atomic Absorption Spectrophotometer (AAS).

\subsection{Pengambilan Sampel}

Data diperoleh dari hasil survei lapang, baik melalui pengamatan langsung dan uji laboratorium. Sampel diambil dari ruas kanan dan kiri jalan. Jumlah titik pengambilan sampel yaitu sebanyak 18 titik, dengan rincian 9 titik di areal persawahan selatan jalan dan 9 titik di areal persawahan utara jalan. Peta lokasi pengambilan sampel (Gambar 1). Pengambilan sampel tanah masing-masing dilakukan dua kali yaitu awal tanam dan menjelang panen. Sampel tanaman padi diambil pada waktu panen, sampel terdiri dari daun, batang, akar dan kulit biji dikumpulkan menjadi satu dilanjutkan menganalisis konsentasi timbal pada sampel. Volume kendaraan bermotor dilakukan pada hari kerja, dalam sehari dilakukan waktu 3 kali yaitu pada pagi, siang dan sore.

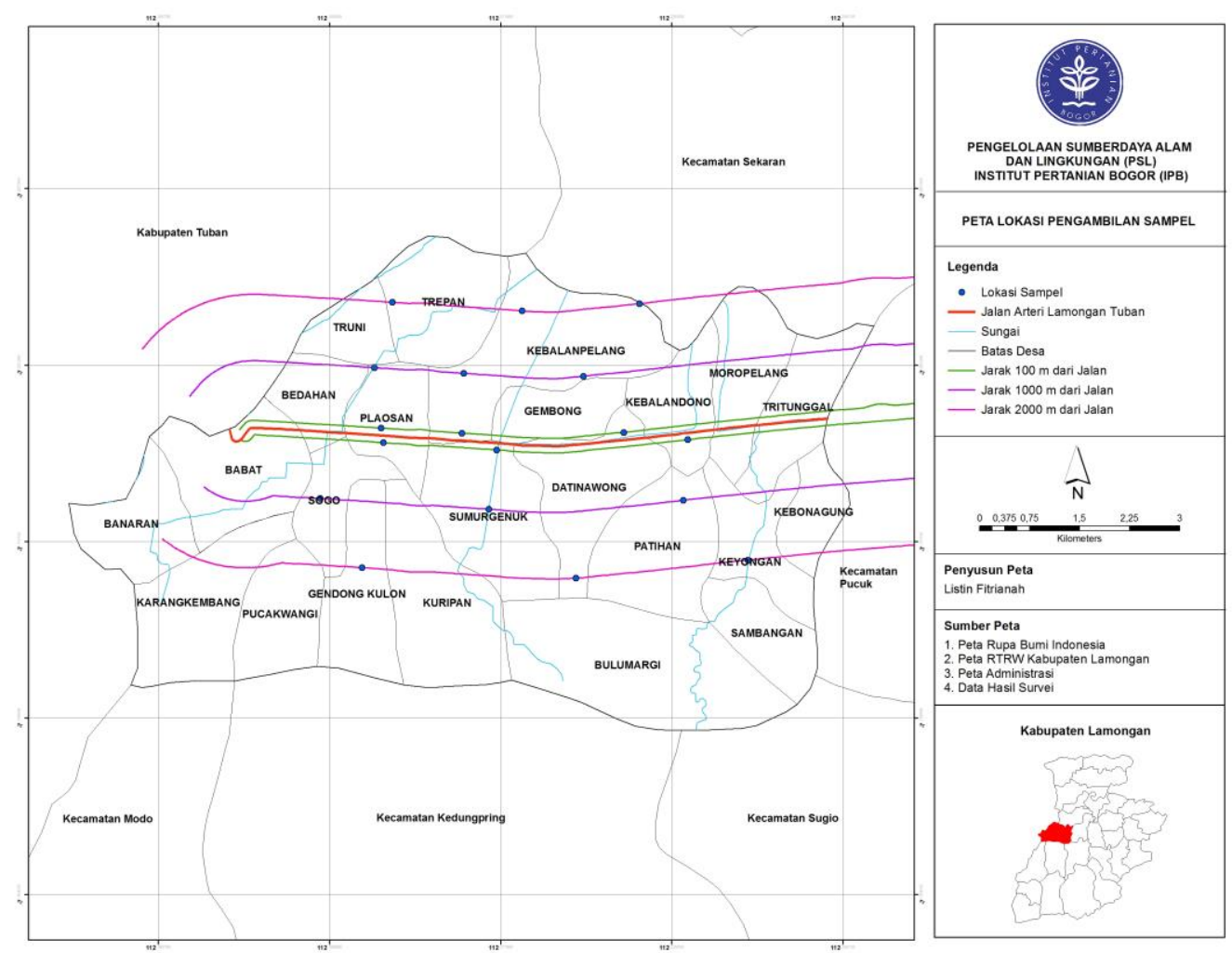

Gambar 1. Peta lokasi pengambilan sampel

\subsection{Analisis Data}

Analisis konsentrasi timbal dalam tanaman padi dimulai dari uji laboratorium terhadap sampel tanah berdasarkan SNI 6986.46-2009 (BSN, 2009). Setelah diperoleh informasi kandungan timbal pada masing- masing sampel yang diuji, maka kemudian dilanjutkan dengan rancangan percobaan tersarang dua tahap.

Analisa Rancangan percobaan yang digunakan Rancangan Tersarang Dua Tahap (Two Stage Nested Design) dengan tiga kali ulangan (Sastrosupadi, 2000). Perlakukan yang digunakan dalam penelitian ini adalah: 
1. Lokasi sawah dari sisi jalan sebagai petak utama (A) yang terdiri atas dua taraf (utara dan selatan jalan).

2. Jarak dari jalan (B) sebagai anak petak yang terdiri atas tiga taraf $(100 \mathrm{~m}$, b. $1000 \mathrm{~m}$, c. 2000 $\mathrm{m})$.

Model persamaan linear dari Rancangan Bersarang Dua Tahap tersebut sebagai berikut :

$$
y_{i j k}=\mu+\tau_{i}+\beta_{j(i)}+\epsilon_{(i j) k}
$$

Keterangan :

Nilai pengamatan level ke-j yang

$\mathrm{Y}_{\mathrm{ijk}}=$ bersarang dalam level ke-i pada ulangan ke-k

$\mu \quad=$ Rataan umum

$\tau_{\mathrm{i}}=$ pengaruh faktor A pada level ke-i

$\beta_{\mathrm{j}(\mathrm{i})}=$ pengaruh faktor $\mathrm{B}$ pada level ke-j yang

$\beta_{\mathrm{j}(\mathrm{i})}=$ bersarang pada faktor A level ke- $\mathrm{i}$ Nilai galat akibat level ke-j yang

$\varepsilon_{(\mathrm{ij}) \mathrm{k}}=$ bersarang dalam level ke-i pada ulangan ke-k

$\mathrm{i}=$ Level-level faktor A

$\mathrm{j}=$ Level-level faktor B yang bersarang di

$\mathrm{j}=$ setiap level faktor $\mathrm{A}$

$\mathrm{k}=$ Jumlah ulangan

Sebaran dari konsentrasi timbal pada beras dilakukan dengan menggunakan analisis spasial dengan sistem informasi geografis (SIG). Metode interpolasi dalam spasial menggunakan (Prahasta 2005), dimana data hasil uji laboratorium timbal pada tanah dan tanaman padi pada masing-masing lokasi sampel kemudian di interpolasi dengan SIG sehingga diperoleh informasi sebaran timbal dilokasi penelitian.

\section{Hasil Dan Pembahasan}

\subsection{Volume Kendaraan Bermotor}

Volume kendaraan bermotor di ruas jalan nasional Lamongan mencerminkan potensi besaran kandungan bahan pencemar yang dihasilkan oleh aktivitas kendaran bermotor. Berdasarkan hasil pengamatan yang telah dilakukan (Tabel 1), maka diperoleh informasi bahwa volume kendaraan bermotor tertinggi terjadi pada pagi hari, dengan rata-rata jumlah kendaraan sebesar 2.877. Sedangkan volume terendah terdapat siang hari dengan rata-rata kendaraan yang melintas sebesar 2.052. Tingginya volume kendaraan pada pagi hari, diakibatkan oleh aktivitas masyarakat menuju tempat kerja (Lamongan kota, Gresik, dan Surabaya).

Berdasarkan Tabel 1, maka dapat dilihat bahwa dari semua jadwal pengamatan kendaraan yang dominan melintas adalah motor, sedangkan yang terendah adalah bus. Volume kendaraan pada pagi hari lebih tinggi dibandingkan pada siang dan sore hari. Mobil dan motor menggunakan bahan bakar jenis premium yang mengandung $\mathrm{Pb}$. Peningkatan jumlah pengguna bahan bakar premium akan meningkatkan sebaran $\mathrm{Pb}$ ke udara ambient. $\mathrm{Pb}$ udara di ambient terdeposit ke lingkungan sekitar (tanah dan tanaman padi).

Tabel 1. Volume dan jenis kendaraaan bermotor

\begin{tabular}{lccc}
\hline \multirow{2}{*}{$\begin{array}{c}\text { Jenis } \\
\text { Kendaraan }\end{array}$} & $06.00-08.00$ & $11.00-13.00$ & $16.00-18.00$ \\
\cline { 2 - 4 } Motor & 4951 & 3312 & 4357 \\
Mobil & 1302 & 1023 & 1147 \\
Bus & 89 & 61 & 87 \\
Truk & 850 & 734 & 1147 \\
Jumlah & 7192 & 5130 & 6738 \\
Rata-rata & 2877 & 2052 & 2965 \\
\hline Keterangan : Hasil pengamatan kendaraan tanggal 24 Maret 2014
\end{tabular}

\subsection{Kandungan Timbal pada Tanah}

Hasil analisis kandungan timbal pada tanah di awal (Januari 2014) dan di akhir tanam (Maret 2014) disajikan dalam Gambar 1. Kandungan timbal tertinggi pada tanah diawal tanam terdapat pada areal sawah sisi selatan dari jalan dengan jarak $2000 \mathrm{~m}$ dari sumber emisi $(53.70 \mathrm{mg} / \mathrm{kg})$, dan kandungan timbal pada tanah diakhir tanam tertinggi terdapat pada areal sawah sisi selatan dengan jarak $1000 \mathrm{~m}$ dari sumber emisi (37.23 mg/kg). Kandungan timbal terendah pada tanah awal tanam terdapat pada areal sawah sisi utara dari jalan dengan jarak $1000 \mathrm{~m}$ sumber emisi (6.94 $\mathrm{mg} / \mathrm{kg}$ ), dan kandungan timbal pada tanah di akhir tanam terendah terdapat pada areal sawah sisi utara dengan jarak $100 \mathrm{~m}$ dari sumber emisi $(7.85 \mathrm{mg} / \mathrm{kg})$. Berdasarkan analisis sidik ragam menunjukkan bahwa lokasi dan jarak dari sumber emisi (jalan raya) tidak berbeda nyata.

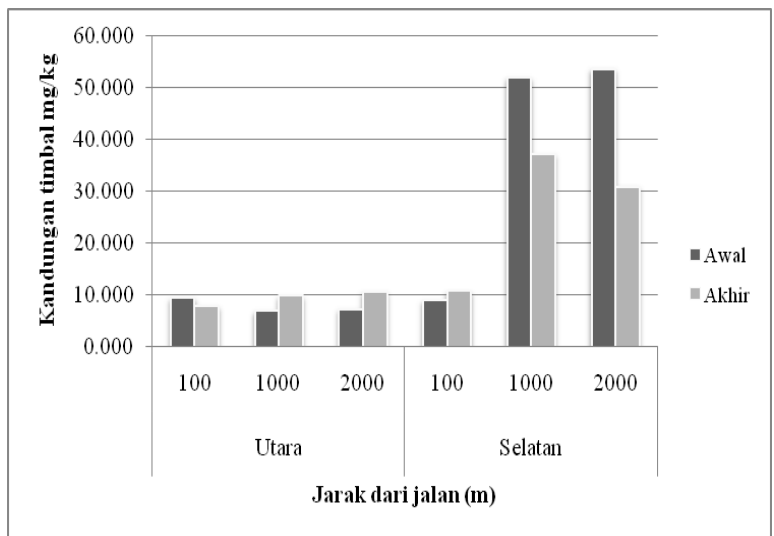

Gambar 2. Kandungan timbal dalam tanah di sisi utara dan selatan jalan pada saat awal dan akhir penanaman padi.

Kandungan timbal pada tanah di awal tanam jarak $100 \mathrm{~m}$ dari ruas jalan bagian utara lebih tinggi dari pada di akhir tanam. Penurunan kandungan timbal pada tanah di akhir tanam menunjukkan adanya penyerapan oleh tanaman padi. Pinta et al. (2005), menyatakan bahwa kandungan logam timbal yang jatuh ke tanah yang diakibatkan oleh angin dan hujan akan diserap oleh tumbuhan melewati akar dan akan disebarkan keseluruh bagian dari tanaman. 
Kandungan logam berat dalam tanah dipengaruhi oleh beberapa faktor, di antaranya jenis tanah dan kondisi tanah, selain itu logam berat masuk ke lingkungan tanah melalui penggunaan bahan kimia yang langsung mengenai tanah, penimbunan debu, hujan, pengikisan tanah dan limbah buangan (Darmono, 1995). Adapun faktor lain yang
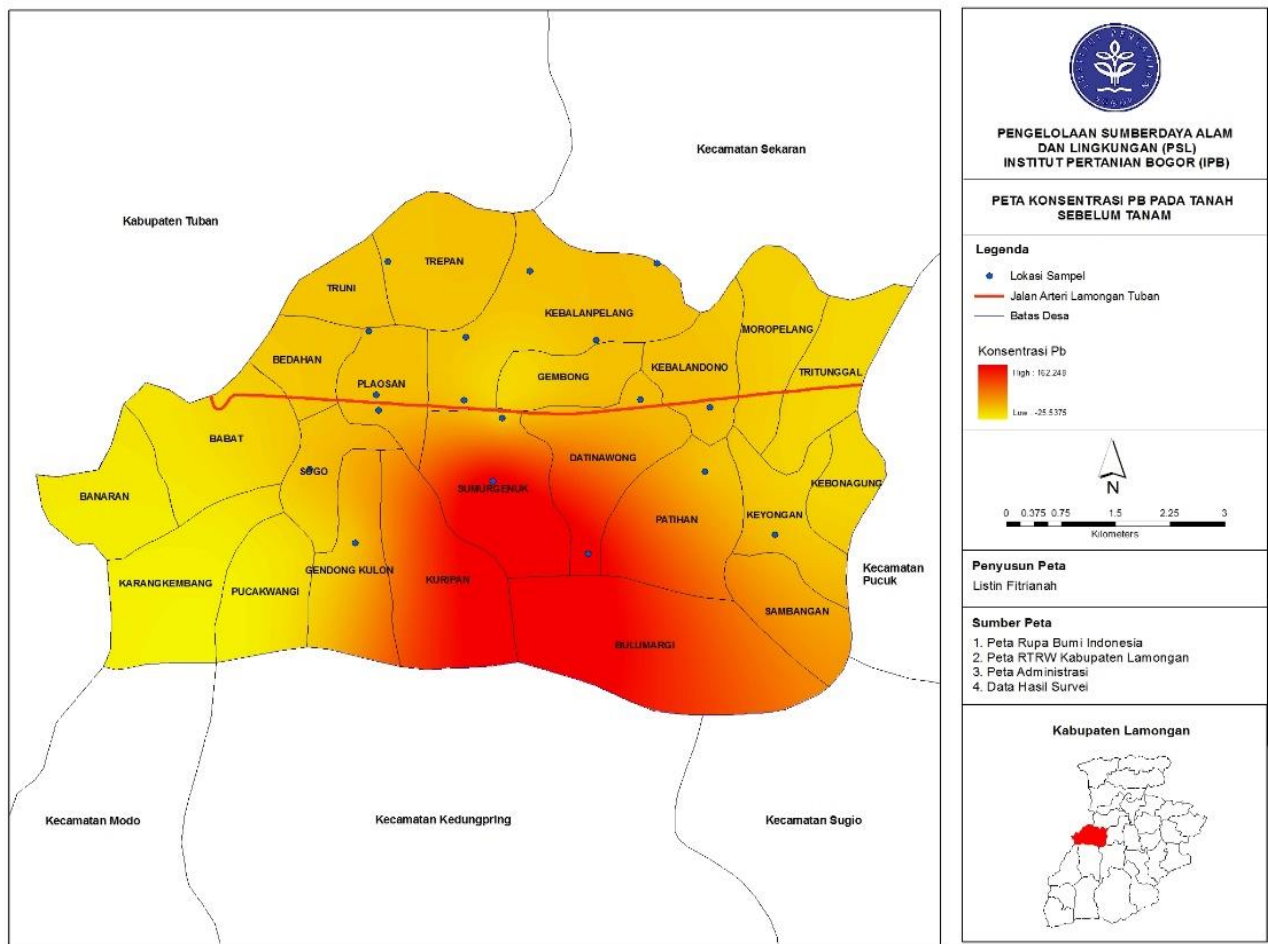

Gambar 3. Sebaran konsentrasi kandungan timbal di tanah pada awal penanaman padi.
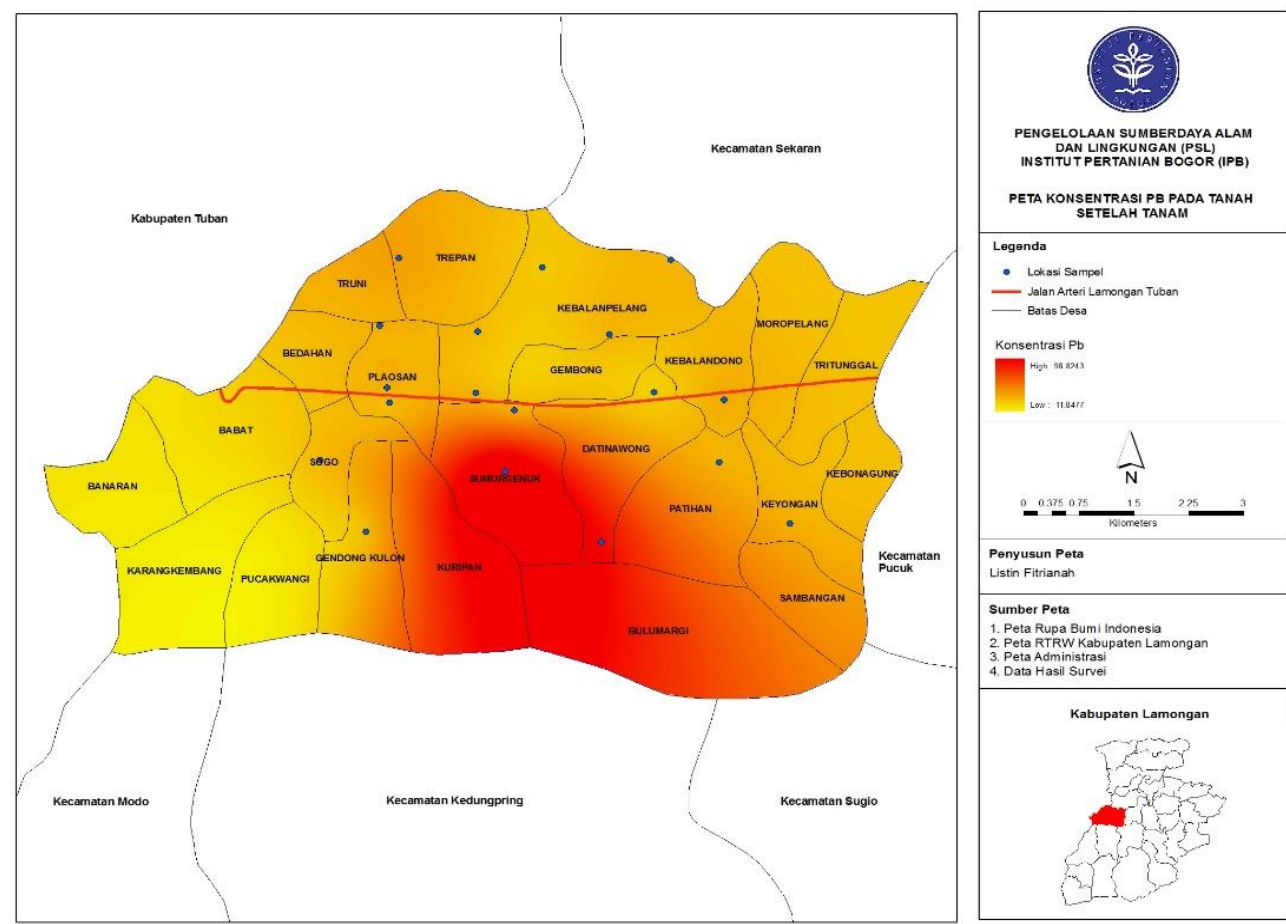

Gambar 4. Sebaran konsentrasi kandungan timbal di tanah pada akhir penanaman padi.

Hasil analisis Kandungan timbal pada tanah akhir penanaman menunjukkan bahwa kandungan timbal pada tanah di dua lokasi yaitu bagian utara dan selatan mempengaruhi kadar $\mathrm{Pb}$ pada tanah adalah penggunaan pupuk organik maupun anorganik dalam aktivitas budidaya.

Sebaran kandungan timbal di tanah pada awal penanaman padi (Gambar 2). Sebaran kandungan timbal di tanah akhir penanaman padi (Gambar 3). 
raya) tidak menunjukkan perbedaan nyata. Kandungan timbal pada tanah setelah tanam tertinggi terdapat pada persawahan bagian selatan dari jalan dengan jarak 1000 meter dari sumber emisi sedangkan yang terendah terdapat pada persawahan bagian utara dari jalan dengan jarak 100 meter dari sumber emisi.

Tingginya kandungan timbal pada tanah pada jarak 2000 (sebelum tanam) dan jarak 1000 (setelah tanam) dari sumber pencemar dapat diartikan bahwa kandungan timbal yang terdapat di tanah berasal dari sumber pencemar lain (penggunaan bahan kimia) dibandingkan dari sumber pencemar kendaraan bermotor, hal dikarenakan sumber pencemar karena timbal yang dibuang ke atmosfer akan mengendap tidak jauh dari sumber emisinya.

Jumlah timbal yang dilepas ke atmosfer hanya $20 \%$ yang terdispersi secara luas dan jarak sebarannya tergantung pada ukuran partikel, sedangkan emisi yang dihasilkan dari kendaraan bermotor sebanyak 20$60 \%$ tetap tertinggal $25 \mathrm{~m}$ dari jalan raya. Partikel dengan diameter $3 \mu \mathrm{m}$ akan mengendap secara gravitasi dalam radius $6-8$ meter, sedangkan partikel berdiameter 5-50 $\mu \mathrm{m}$ mengendap secara gravitasi dalam radius 12 meter (Niagru, 1979 dalam WHO, 1995). Timbal dalam beberapa kasus diidentifikasi susah untuk larut dan masuk kedalam tanah dan terakumulasi dalam ekosistem tempat timbal tersebut terendap, sehingga timbal sulit untuk dihilangkan.

Sampel tanah awal tanam menunjukkan nilai probability nya sebesar $0.1641>5 \%$ yang menunjukkan bahwa Lokasi tidak berpengaruh terhadap tanah_awal pada taraf nyata 5\% dan tidak dapat dilakukan uji lanjut. Hasil menunjukkan nilai probability nya sebesar $0.7298>5 \%$ yang menunjukkan bahwa Jarak tidak berpengaruh terhadap tanah awal pada taraf nyata $5 \%$ dan tidak dapat dilakukan uji lanjut. Sampel tanah awal tanam menunjukkan nilai probability nya sebesar sebesar $0.1717>5 \%$ yang menunjukkan bahwa Lokasi tidak berpengaruh terhadap tanah_akhir pada taraf nyata 5\% dan tidak dapat dilakukan uji lanjut. Hasil menunjukkan nilai probability nya sebesar $0.7503>$ $5 \%$ yang menunjukkan bahwa Jarak tidak berpengaruh terhadap tanah akhir pada taraf nyata 5\% dan tidak dapat dilakukan uji lanjut.

Hasil menunjukkan nilai sig. $0.000<5 \%$ terdapat hubungan yang nyata antara Tanah awal dengan Tanah akhir. Nilai 0.971 menunjukkan bahwa korelasi Tanah awal dengan Tanah akhir kuat dan berkorelasi positif. Hal ini karena kandungan logam berat dalam tanah dipengaruhi oleh beberapa faktor, diantaranya jenis tanah dan kondisi tanah, selain itu logam berat masuk ke lingkungan tanah melalui penggunaan bahan kimia yang langsung mengenai tanah, penimbunan debu, hujan, pengikisan tanah dan limbah buangan (Darmono,1995). Adapun faktor lain yang memengaruhi kadar $\mathrm{Pb}$ pada tanah seperti pada waktu pemberian pupuk saat bertanam baik pupuk organik maupun anorganik karena di dalam pupuk anorganik mengandung bahan kimia untuk menambah atau menggantikan unsur hara yang hilang terserap oleh pertanaman sebelumnya, juga dapat tercuci oleh aliran air hujan atau bereaksi dengan unsur kimia lain yang berpengaruh terhadap kadar $\mathrm{Pb}$ pada tanah (Hernawati et al 2014).

\subsection{Kandungan Timbal pada Tanaman Padi}

Hasil analisis kandungan timbal pada tanaman di akhir tanam (Maret 2014) disajikan dalam Gambar 3. Kandungan timbal pada tanaman padi menunjukkan bahwa kandungan timbal pada tanaman berdasarkan lokasi (sisi utara dan selatan) dari jalan raya tidak berbeda nyata. Sedangkan kandungan timbal pada tanaman berdasarkan fungsi jarak dari sumber emisi (jalan raya) menunjukkan perbedaan nyata. Kandungan timbal pada tanaman tertinggi terdapat pada areal sawah sisi utara dari jalan dengan jarak 100 $\mathrm{m}$ dari sumber emisi $(0,052 \mathrm{mg} / \mathrm{kg})$, sedangkan yang terendah terdapat pada areal sawah sisi selatan dari jalan dengan jarak $2000 \mathrm{~m}$ dari sumber emisi $(0,003$ $\mathrm{mg} / \mathrm{kg}$ ). Informasi rata-rata kandungan timbal pada tanaman padi (Gambar 4) dan sebaran timbal pada tanaman padi (Gambar 5).

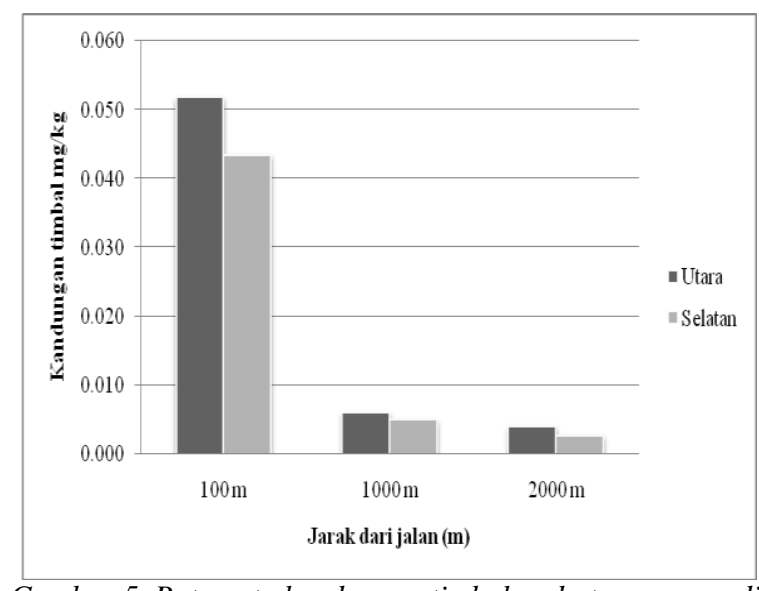

Gambar 5. Rata-rata kandungan timbal pada tanaman padi.

Berdasarkan hasil analisis sebagaimana ditunjukkan pada Gambar 3 dan Gambar 4 diperoleh informasi bahwa kandungan timbal tertinggi terdapat pada jarak $100 \mathrm{~m}$ dari sumber emisi baik untuk lokasi utara maupun selatan. Besarnya kandungan timbal pada tanaman pada jarak $100 \mathrm{~m}$ dapat dipengaruhi oleh beberapa faktor yaitu volume atau kepadatan lalu lintas, jarak dari sumber emisi, lama waktu kontak dengan timbal, kadar timbal dalam tanah, kadar timbal dalam air. Arah angin juga berperan dalam proses sebaran kandungan bahan pencemar $(\mathrm{Pb})$, hal ini dapat dilihat dari kandungan timbal pada tanaman tertinggi terdapat pada sisi utara jarak $100 \mathrm{~m}$ dari ruas jalan, dan kandungan timbal pada jarak $100 \mathrm{~m}, 1000 \mathrm{~m}$ dan $2000 \mathrm{~m}$ dari ruas jalan sisi selatan memiliki kandungan lebih rendah dibandingkan lokasi sisi utara. Kondisi tersebut sejalan waktu panen tanaman padi yang dilakukan bulan Maret dan April, dimana arah angin pada bulan tersebut lebih banyak ke arah utara, sehingga sebaran bahan pencemar yang dilepaskan ke udara lebih banyak terkandungan di sisi utara. 
Menurut Priyanto dan Prayitno (2007), logam berat yang masuk ke dalam tanaman akan berikatan dengan unsur hara lain dan mengalami imbobilisasi ke bagian tanaman tertentu dan tidak dapat diedarkan ke seluruh tanaman karena telah mengalami proses detoksifikasi (penimbunan pada organ tertentu) sehingga tanaman masih dapat tumbuh dan unsur hara yang diperlukan tanaman masih mampu untuk mensuplai pertumbuhan tanaman meskipun tercemar logam berat $\mathrm{Pb}$.
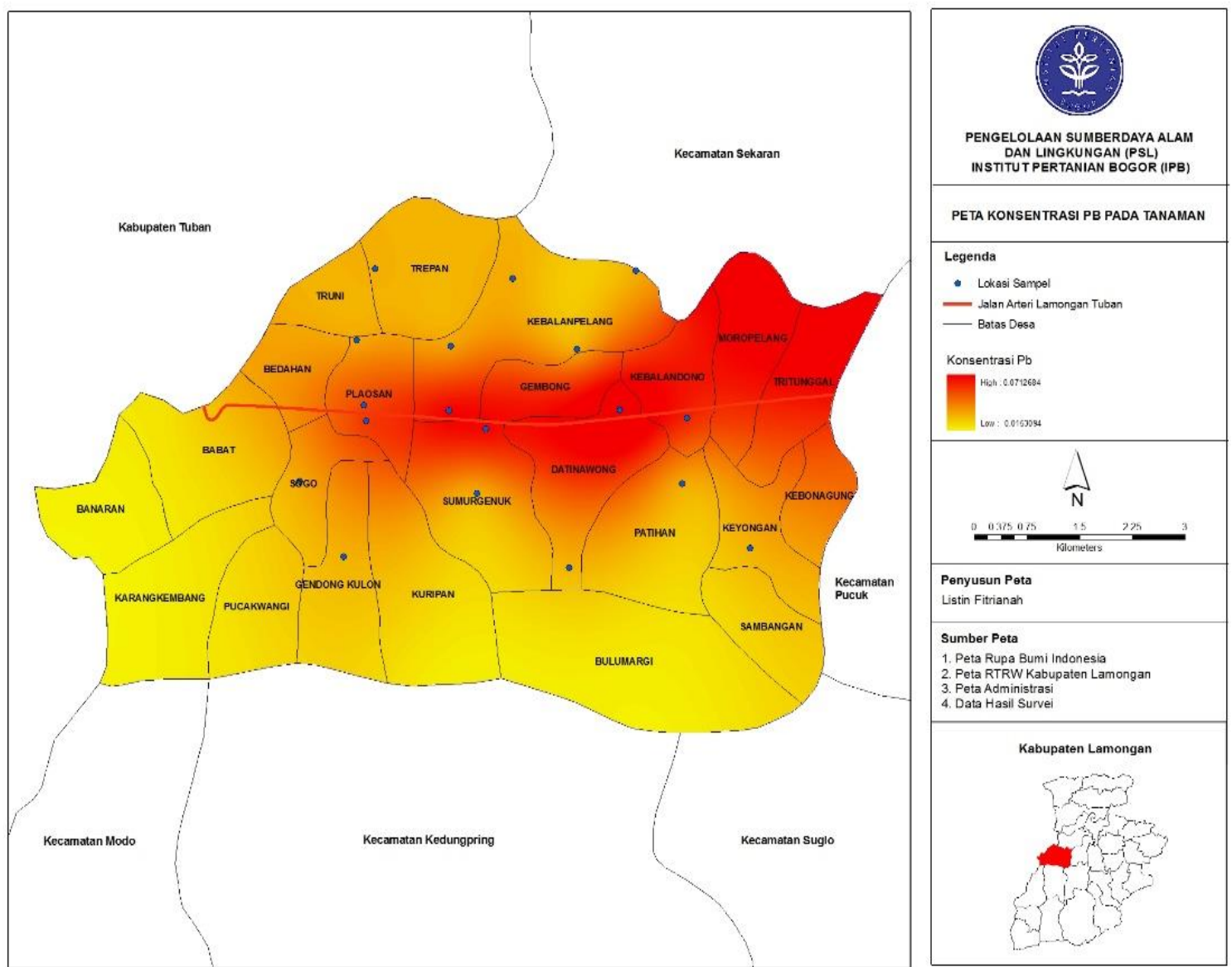

Gambar 6. Sebaran kandungan timbal pada tanaman padi.

Treshow dan Anderson (1989), menyatakan bahwa jumlah timbal di udara dipengaruhi oleh oleh volume atau kepadatan lalu lintas, jarak dari jalan raya, daerah industri, kecepatan mesin, dan arah angin. Disamping itu besarnya kandungan timbal pada tumbuhan dipengaruhi oleh sedimentasi dan tumbukan yang terjadi. Menurut Gidding (1973), partikel yang diemisikan kendaraan bermotor berukuran antara $0.004-1.0 \mu \mathrm{m}$. timbal yang berukuran kecil sebelum jatuh ke air, tanah, dan tanaman akan melayang beberapa saat diudara bebas. Jatuhnya timbal disebabkan oleh proses sedimentasi akibat gaya gravitasi, dan pengendapan yang berhubungan dengan hujan.

Sampel tanaman padi menunjukkan nilai probability nya sebesar $0.3944>5 \%$ yang menunjukkan bahwa Lokasi tidak berpengaruh terhadap tanaman pada taraf nyata $5 \%$ dan tidak dapat dilakukan uji lanjut. Hasil menunjukkan nilai probability nya sebesar $0.0001<5 \%$ yang menunjukkan bahwa Jarak berpengaruh terhadap tanaman pada taraf nyata 5\% dan dapat dilakukan uji lanjut. Hasil uji lanjut ditunjukka pada tabel 2.

Besarnya kandungan timbal dalam air, tanah, dan tanaman akan berpengaruh terhadap besaran kandungan timbal dalam beras. Hal ini dikarenakan tanah dan air merupakan komponen utama dalam proses pertumbuhan tanaman. Tanah merupakan media tumbuh tanaman yang mendukung pertumbuhan dan perkembangan tanaman. Sedangkan air berfungsi sebagai penunjang dalam berlangsungnya reaksi biokimia. Oleh karena itu, akumulasi timbal yang dihasilkan dari aktivitas kendaraan bermotor yang dilepaskan ke atmosfer yang jatuh ke tanaman akan diserap oleh daun melalui stomata, sedangkan bahan pencemar yang jatuh ke air dan tanah diserap oleh akar yang kemudian ditranslokasi di dalam tanaman, dan pada akhirnya sebagain akan terkandungan pada buah (beras).

Berdasarkan informasi sebagaimana diuraikan pada kandungan timbal pada tanaman dan beras diatas, diperoleh informasi bahwa fungsi jarak dari sumber emisi berpengaruh terhadap tanaman dan beras pada taraf nyata 5\%. Oleh karena itu dapat dilakukan uji lanjut. Hasil analisis uji lanjut pada tanaman dan beras berdasarkan jarak lokasi (Tabel 2). 
Tabel 2. Hasil analisis uji lanjut pada tanaman padi

\begin{tabular}{cc}
\hline Jarak Lokasi & Tanaman \\
\hline Utara 100 & $0.061 \mathrm{a}$ \\
Selatan 100 & $0.043 \mathrm{~b}$ \\
Utara 1000 & $0.006 \mathrm{cc}$ \\
Selatan 1000 & $0.004 \mathrm{cc}$ \\
Utara 2000 & $0.004 \mathrm{cc}$ \\
Selatan 2000 & $0.003 \mathrm{c}$
\end{tabular}

Keterangan : Angka-angka yang diikuti dengan huruf yang sama tidak berbeda nyata berdasarkan uji Duncan $5 \%$

Lokasi utara jarak 100 meter dari ruas jalan berpengaruh nyata pada lokasi selatan 100 meter dari ruas jalan. Giddings (1973) menyebutkan partikel timbal yang diemisikan kendaraan bermotor berukuran antara $0.004-1.0 \pi \mathrm{m}$. Timbal adalah partikel yang berukuran kecil dan sebelum jatuh ke permukaan tanaman dan tanah timbal akan melayang-layang beberapa saat di udara bebas, namun akhirnya akan jatuh ke permukaan tanaman ataupun ke tanah. Jatuhnya timbal dari udara ke permukaan tanah ataupun tanaman terjadi karena proses sedimentasi akibat gaya gravitasi dan pengendapan akibat adanya hujan. Mariti (2005) menjelaskan besarnya kandungan logam timbal yang terdapat dalam setiap sampel berasal dari gas buangan kendaraan bermotor yang akan terbang ke udara, sebagian akan menempel pada tanaman sayur yang berada di pinggir jalan raya dan sebagian lagi dengan adanya angin dan hujan akan mengakibatkan debu tersebut jatuh ke permukaan tanah dan jalan raya. Senyawa timbal yang menempel pada tanaman lama-kelamaan akan teradsorbsi masuk ke dalam daun, sedangkan yang jatuh ke tanah akan diserap oleh tumbuhan melewati akar dan akan disebarkan keseluruh bagian dari tanaman tersebut.

Kandungan timbal tanaman pada jarak 1000 dan 2000 meter dari ruas jalan lokasi utara maupun selatan tidak ada pengaruh nyata. Menurut Alloway (1995) logam $\mathrm{Pb}$ diserap oleh tanaman pada saat kandungan bahan organik dan kondisi kesuburan tanah rendah, selain itu komposisi dan $\mathrm{pH}$ tanah, serta Kapasitas Tukar Kation (KTK) juga mempengaruhi perpindahan $\mathrm{Pb}$ dari tanah ke tanaman. Logam berat $\mathrm{Pb}$ pada keadaan ini akan terlepas dari ikatan tanah berupa ion yang bergerak bebas kemudian diserap oleh tanaman melalui pertukaran ion. Logam berat $\mathrm{Pb}$ terserap oleh akar tanaman apabila logam lain tidak mampu menghambat keberadaannya. Hal ini akan mengakibatkan tanah akan didominasi oleh kation $\mathrm{Pb}$, sehingga menyebabkan kation lain ketersediaannya berkurang dalam kompleks serapan akar. Kation $\mathrm{Pb}$ yang terserap oleh akar masuk kedalam tanaman akan menjadi inhibitor pembentukan enzim kemudian akan menghambat proses metabolime tanaman, yang meliputi proses respirasi yang nantinya akan menghasilkan ATP yang digunakan untuk fotosintesis, kemudian hasil fotosintesis akan digunakan diedarkan untuk pembelahan sel (tinggi, jumlah dan biomassa) dan reproduksi akan terganggu. Apabila ini dilakukan terus menerus dalam jangka waktu panjang akan menyebabkan menurunnya kualitas pertumbuhan tanaman padi dan mengakibatkan pertumbuhan tanaman terganggu.

Akumulasi timbal pada tanaman erat kaitannya dengan dengan sistem berkas pengangkutan dalam tanaman. Bahan pencemar yang ada atmosfer yang jatuh ke tanaman akan diserap oleh daun melalui stomata, sedangkan bahan pencemar yang jatuh ke air dan tanah diserap oleh akar yang kemudian ditranslokasi di dalam tanaman. Kadar $\mathrm{Pb}$ di air dan tanah memengaruhi kadar $\mathrm{Pb}$ pada tanaman padi.. Menurut Alloway (1995) logam $\mathrm{Pb}$ diserap oleh tanaman pada saat kandungan bahan organik dan kondisi kesuburan tanah rendah, selain itu komposisi dan pH tanah, serta Kapasitas Tukar Kation (KTK) juga mempengaruhi perpindahan $\mathrm{Pb}$ dari tanah ke tanaman. Logam berat $\mathrm{Pb}$ pada keadaan ini akan terlepas dari ikatan tanah berupa ion yang bergerak bebas kemudian diserap oleh tanaman melalui pertukaran ion. Logam berat $\mathrm{Pb}$ terserap oleh akar tanaman apabila logam lain tidak mampu menghambat keberadaannya. Hal ini akan mengakibatkan tanah akan didominasi oleh kation $\mathrm{Pb}$, sehingga menyebabkan kation lain ketersediaannya berkurang dalam kompleks serapan akar. Kation $\mathrm{Pb}$ yang terserap oleh akar masuk kedalam tanaman akan menjadi inhibitor pembentukan enzim kemudian akan menghambat proses metabolime tanaman, yang meliputi proses respirasi yang nantinya akan menghasilkan ATP yang digunakan untuk fotosintesis, kemudian hasil fotosintesis akan digunakan diedarkan untuk pembelahan sel (tinggi, jumlah dan biomassa) dan reproduksi akan terganggu. Apabila ini dilakukan terus menerus dalam jangka waktu panjang akan menyebabkan menurunnya kualitas pertumbuhan tanaman padi dan mengakibatkan pertumbuhan tanaman terganggu.

Menurut Priyanto dan Prayitno (2007) logam berat yang masuk ke dalam tanaman akan berikatan dengan unsur hara lain dan mengalami imbobilisasi ke bagian tanaman tertentu dan tidak dapat diedarkan ke seluruh tanaman karena telah mengalami proses detoksifikasi (penimbunan pada organ tertentu) sehingga tanaman masih dapat tumbuh dan unsur hara yang diperlukan tanaman masih mampu untuk mensuplai pertumbuhan tanaman meskipun tercemar logam berat $\mathrm{Pb}$. Salah satu unsur hara yang dapat dijadikan contoh dalam proses KTK (Kapasitas Tukar Kation) adalah unsur hara K. Rohyanti et al. (2011) menyatakan bahwa unsur $\mathrm{K}$ berperan dalam mendukung pertumbuhan tanaman, yaitu unsur $\mathrm{K}$ berperan dalam hal fotosintesis tanaman. Proses fotosintesis tanaman akan menghasilkan karbohidrat, protein dan senyawa organik lainnya. Senyawa-senyawa yang dihasilkan dipergunakan dalam proses pembelahan dan pembesaran atau diferensiasi selsel tanaman. Berlangsungnya pembelahan dan perpanjangan sel sel tanaman akan memacu pertumbuhan pada tunas-tunas pucuk tanaman dan akhirnya akan mendorong terjadinya penambahan tinggi tanaman. Senyawasenyawa yang dihasilkan dipergunakan dalam proses pembelahan dan pembesaran atau diferensiasi selsel tanaman. Berlangsungnya pembelahan dan 
perpanjangan sel-sel tanaman akan memacu pertumbuhan pada tunas-tunas pucuk tanaman dan akhirnya akan mendorong terjadinya penambahan tinggi tanaman, jumlah daun dan biomassa tanaman. Kandungan unsur $\mathrm{K}$ rendah dan logam berat $\mathrm{Pb}$ sangat tinggi pada menyebabkan konsentrasi unsur hara dalam tanah tidak seimbang. $\mathrm{Pb}$ yang tinggi akan menyebabkan proses penyerapan unsur hara oleh tanaman akan mengalami perbedaan karena jumlah kation $\mathrm{Pb}$ dalam tanah lebih banyak dibandingkan unsur hara yang diperlukan oleh tanaman (Silaban dkk., 2013). Dwidjoseputro (1998) menyatakan bahwa suatu tanaman akan tumbuh baik dan subur apabila semua unsur hara yang dibutuhkan berada dalam jumlah yang cukup dan tersedia bagi tanaman. Lingga dan Marsono (1999) juga mengemukakan jika unsur hara yang dibutuhkan tanaman tersedia dalam jumlah yang cukup, maka hasil metabolisme seperti sintesis biomolekul akan meningkat. Hal ini menyebabkan pembelahan sel, pemanjangan dan pendewasaan jaringan menjadi lebih sempurna dan cepat, sehingga pertambahan volume dan bobot semakin cepat yang pada akhirnya pertumbuhan tanaman menjadi lebih baik.

\section{Kesimpulan}

Berdasarkan hasil penelitian dapat disimpulkan kandungan timbal pada tanah sebelum tanam tertinggi terdapat pada persawahan bagian selatan dari jalan dengan jarak $2000 \mathrm{~m}$ dari sumber emisi, sedangkan yang terendah terdapat pada persawahan bagian selatan dari jalan dengan jarak $1000 \mathrm{~m}$ dari sumber emisi. Kandungan timbal pada tanah setelah tanam tertinggi terdapat pada persawahan bagian selatan dari jalan dengan jarak 1000 meter dari sumber emisi sedangkan yang terendah terdapat pada persawahan bagian utara dari jalan dengan jarak 100 meter dari sumber emisi. Kandungan timbal pada tanaman tertinggi terdapat pada persawahan bagian utara dari jalan dengan jarak 100 meter dari sumber emisi, sedangkan yang terendah terdapat pada persawahan bagian selatan dari jalan dengan jarak 2000 meter dari sumber emisi. Semakin jauh lokasi tanaman di ruas jalan semakin sedikit jumlah timbal pada tanaman.

\section{Daftar Pustaka}

[1] [BSN] Badan Standarisasi Nasional, 2009. Cara Uji Timbal Secara Spektrofotometri Serapan Atom. SNI No 6986.462009, Jakarta.
[2] Alloway B. J., 1995. Heavy Metals in Soils. Second Edition. Blackie Academic \& Professional. An Imprint of Chapman \& Hall, Glasgow.

[3] Darmono, 1995. Logam dalam Sistem Makhluk Hidup. UIPress, Jakarta.

[4] Dwidjoseputro D., 1998. Pengantar Fisiologi Tumbuhan. Gramedia, Jakarta.

[5] Gidding, J. C., 1973. Chemistry, Mans and Environmental Changes: An Integrated Approach. Canfield, San Fransisco, New York.

[6] Lingga, P., Marsono, 1994. Petunjuk Penggunaan Pupuk. Penebar Swadaya, Jakarta.

[7] Pinta E., et al. 2015. Analisis Kandungan Logam Timbal pada Sayur Kangkung dan Bayam di Jalan Kartama Pekanbaru Secara Spektrofotometri Serapan Atom. JOM FMIPA 2(1), pp. 75-82.

[8] Priyanto B. dan J. Prayitno, 2007. Fitoremidiasi Sebagai Sebuah Teknologi Pemulihan Pencemaran Khususnya Logam Berat. http://ltl.bppt.tripod.com/sublab/lflora 1.html [13 Oktober 2015]

[9] Rohyanti, Muchyar, dan N. Hayani, 2011. Pengaruh Pemberian Bokashi Jerami Padi terhadap Pertumbuhan Vegetatif Tanaman Tomat (Lycopersicum esculentum mill) di Tanah Podsolik Merah Kuning. Jurnal Wahana-Bio. 4, pp. 26-29.

[10] Sastrosupadi, A., 2000. Rancangan Percobaan Praktis Bidang Pertanian. Penerbit Kanisius, Yogyakarta

[11] Silaban, S. Nia, Nelvia, Idwar, 2013. Pertumbuhan Tanaman Padi Fase Vegetatif dan Akumulasi Logam Berat Pada Jaringan Tanaman Padi Varietas Payo Besar dan Inpari 12 di Lahan Gambut yang diberi Amelioran Dregs. Jurusan Agroteknologi Fakultas Pertanian Universitas Riau, Pekanbaru.

[12] Surani, R., 2002. Pencemaran dan Toksikologi Logam Berat Rineka Cipta, Jakarta.

[13] Treshow, M. F, A. Anderso, 1989. Plant Stress from Air Pollution. John Wiley and Son Ltd. Chisester, New York. 